\title{
PARQUE URBANO CULTURAL: MOVIMENTO ARTÍSTICO E URBANIZAÇÃO
}

\author{
Marília da Rocha Lote ${ }^{1}$ \\ Fernanda Cota Trindade ${ }^{2}$
}

Resumo: Pode-se apresentar o homem como principal agente da relação do ambiente natural e o espaço urbano. O homem nasce com a cultura e a cultura o define, e ela é capaz de promover a integração entre as pessoas e a transformação no meio social. A inserção de Parques Urbanos Culturais na paisagem da cidade busca o revir da cultura local, a melhoria da imagem da cidade e da relação do ambiente natural com o ambiente construído. Em se tratando da Cidade de Manhuaçu/MG, o ambiente cultural é pouco valorizado e esse pode ser reestruturado através de um Parque Urbano com parâmetros voltados para a cultural local. A criação de um parque urbano como um centro voltado para a cultura, integrado ao entorno, e que seja capaz de atender a população local, a partir dos preceitos de uma melhor utilização do espaço à qualidade de vida urbana, como densidade, diversidade, mobilidade e a identidade da cidade, com foco em uma melhoria sustentável, inteligente e criativa se mostra positiva para melhorar a relação homem/cultura/meio natural.

Palavras-chave: Parque Urbano; Paisagem urbana; Cultura; Ambiente natural.

1 Graduada em Arquitetura e Urbanismo/Faculdade de Ciências Gerenciais de Manhuaçu, Brasil. E-mail: marilialote@gmail.com.

2 Mestre em Arquitetura e Urbanismo/Faculdade de Ciências Gerenciais de Manhuaçu, Brasil. E-mail: fercotat@hotmail.com. 